\title{
State-Building, Power-Sharing Discourse, and Political Autonomy of Minorities within Ethno-Nationalist Gloom in Sri Lanka
}

\author{
Mohammad Agus Yusoff ${ }^{1}$, Athambawa Sarjoon ${ }^{1,2}$ \& Abd Rashid Abdul Wahab ${ }^{3}$ \\ ${ }^{1}$ School of History, Politics and Strategic Studies, Faculty of Social Sciences and Humanities, Universiti \\ Kebangsaan Malaysia, UKM Bangi 43600, Selangor, Malaysia \\ ${ }^{2}$ Department of Political Science, University of Peradeniya, Peradeniya 20400, Sri Lanka \\ ${ }^{3} \mathrm{PhD}$ Candidate, Faculty of Human Ecology, Universiti Putra Malaysia, 43400 UPM Serdang, Selangor, \\ Malaysia
}

Correspondence: Mohammad Agus Yusoff, School of History, Politics and Strategic Studies, Faculty of Social Sciences and Humanities, Universiti Kebangsaan Malaysia, UKM Bangi 43600, Selangor, Malaysia. Tel: 60-19-338-0962. E-mail: agus_ukm@yahoo.com

\author{
Received: December 21, 2015 Accepted: January 23, 2016 Online Published: February 28, 2016 \\ doi:10.5539/jpl.v9n1p88 \\ URL: http://dx.doi.org/10.5539/jpl.v9n1p88
}

\begin{abstract}
Positioning minority concerns within a power-sharing mechanism is a key issue that has been influential in Sri Lanka's modern state-building process experimented from the later part of the colonial period. Throughout the post-independent era, most state-building projects were critically debated with regard to sharing political autonomy between the majority Sinhalese and the minorities. This study attempts to locate the claims and concerns of minorities seeking political autonomy in Sri Lanka's state-building and power-sharing discourse. The study found that the state-building process in Sri Lanka has always been a struggle between establishing a majoritarian-ethno-nationalist hegemonic state system and preserving the right of minority ethnic groups to political power-sharing. The study further found that (a) insufficient emphasis given towards understanding power-sharing and federalism as a means to accommodate diverse interests and rights, including the political autonomy rights of minorities, (b) the opportunistic politics of opposition parties, and (c) the ethno-nationalist agenda of the majority Sinhalese were the major factors that have induced to undermine the minorities' claims for political autonomy. The ultimate result of this is the continuous struggles by minorities to situate their political autonomy demands within Sri Lanka's state-building and power-sharing discourse.
\end{abstract}

Keywords: State-building, power-sharing, political autonomy, ethno-nationalism, minorities, Sri Lanka

\section{Introduction}

One major area of concern in terms of accommodating rights and interests of minorities in post-colonial Sri Lanka is the country's state-building projects, which have been widely contested and criticized. Since the late colonial period, Sri Lanka has been subject to modern democratic state-building experiments, principally in the electoral political arena due to the deliberate attempts by the Sinhalese and Tamil political elites to share political power among the major ethnic groups. Sri Lanka inherited a highly centralized state structure from the colonial period. Although in the 1920s, some political leaders and representatives put forward the idea of a power-sharing mechanism - federal form of state - for Sri Lanka, the idea was neglected, and the concept of regional [political] autonomy was not incorporated in the process of framing the structure of the newly independent country. Instead, Sri Lanka emerged as a state with a centralized form of government similar to the British Westminster model. Though Sri Lanka began its independence with a strong pluralistic orientation, ethnic thinking was developed through colonial experiments with ethnic representation in the early 1900s, and, with increasing state centralization, ethnicity became a dominant category in the post-colonial period. Similarly, state-building projects were also avoided to accommodate the interests and claims of ethnic minorities in terms of providing political autonomy. The ultimate result was the break-up of ethnic relations between the major ethnic groups on one hand, and the failure to complete comprehensive state-building projects on the other hand. There were many opportunities for the leaders of all major ethnic groups to build consensus in matters of the nature of state, state structure, and means of sharing powers among ethnic groups. However, since ethno-nationalism of ethnic majorities predominated in the entire state-building and power-sharing discourse as well as the socio-political 
domain, most of these opportunities were not taken advantage of. The continuous negligence of the minority leaders regarding their concerns for power-sharing and political autonomy compelled the minorities to search for alternative mechanisms; consequently, they mobilized for their own political liberation. This led to an ethno-political conflict and a 30-year-long civil war. The end of civil war in Sri Lanka created hopes among minorities that their concerns towards power-sharing and political autonomy would be accommodated in the post-civil war democratization process. However, the post-civil war scenario not only boosted the re-emergence of ethno-nationalism but also served to further centralize the state's power. Despite pressures, claims, and criticisms, the accommodation of the political autonomy claims of minorities is still questionable. This paper attempts to examine the nature of Sri Lanka's state-building and power-sharing discourses and the extent of the accommodation of minorities' political autonomy claims. This paper is an outcome of a three-year research project, which examined the role of minorities in the development administration process. This research incorporated only secondary data collected from different sources.

\section{Minority Concerns and Claims for Political Autonomy in the State-Building Process}

\subsection{Setting the Scene}

Even though Sri Lankan society has long been a plural one in terms of ethnicity and religion, initially there were no struggles for political power between different groups; history reveals that both the ethnic majorities and the ethnic minorities lived together and ruled together. However, with the arrival of the colonial powers and their divide and rule system, a clash between majorities and minorities emerged in terms of sharing state power and living politically autonomously from each other. This rivalry for political power between ethnic groups started particularly in the later part of British colonial rule, which on one hand introduced a modern system of governance and contemporary political concepts or principles in the country, but on the other hand also led to polarizations within Sri Lankan society. There were worrying concerns among the minorities and some sections of the majorities over the nature of the state and government of independent Sri Lanka. They preferred a power-sharing federal form of government with mechanisms for protecting their rights and privileges of all groups. However, the concerns of minorities were never considered in the state-building process, and the successive constitutional reforms during the post-colonial period continued to further centralize the state's power. The enactment of the first republican constitution in 1972 removed Sri Lanka's status as a "British colony." Nonetheless, it created a new political structure that concentrated all powers in legislature, called the "National State Assembly." Partly to palliate the Sinhalese nationalists who were dissatisfied with the conciliatory alleviation of Tamil grievances, the constitution then declared Sri Lanka "a unitary state," gave Buddhism the foremost place in terms of religion and made it the state's duty "to protect and foster Buddhism," instituted Sinhala as the "official language of Sri Lanka," and mandated that the regulations drafted under the Tamil Language Act of 1958 were only "subordinate legislation" (Feebles, 2006 \& Wickramaratne, 2010). The second republican constitution (1978) also made power-sharing in Sri Lanka impossible, due to the introduction of a unitary republic and the executive presidency system. All these constitutional provisions, according to Manikkalingam (2003:3), were established with a Sinhalese liberalist perspective that supported a unitary state out of belief that it ensured individual equality, as opposed to power-sharing or federalism because federalism was seen as a concession to Tamil nationalist demands that were viewed as potentially aggravating the conflict. As Perera (2012) argued, the $18^{\text {th }}$ amendment to the present constitution made in 2010 further helped to legalize the centralization of power and the control of the central government over the state machinery by ensuring that all top officers of the state were beholden to the President for having appointed them. Regime change at the beginning of 2015 and the constitutional reform it made in April of the same year created a hope for rebuilding not only the fragile Sri Lankan state, but also democracy, civil society, and good governance. However, positioning minority concerns and demands, especially their political autonomy demands, is still a contested topic for debate among political elites and nationalist forces.

The majority Sinhalese have always undermined the continuous claim of minorities that state powers should be shared among ethnic groups. The Sinhalese-dominated successive governments by mobilizing the ordinary public in terms of ethno-nationalism also continued to oppose minorities' right to political autonomy while framing their claims as a threat to the territorial integrity of the country. In this process, Buddhist revivalism also played a vital role in mobilizing the majority Sinhalese towards ethno-nationalism, which advocated for the protection of the Sinhalese and Buddhism in Sri Lanka. It is a noteworthy fact that the Buddhist revival movement under Anagarika Dharmapala (1864-1933), who is identified as the founder of Sinhala-Buddhist-ethno-nationalism in Sri Lanka, has given the Sinhalese the ideology of a Sinhala-Buddhist state. Dharmapala was a champion of Sinhalese nationalism and vehemently attacked minorities in his writings. His glorification of the Sinhalese Buddhist identity was based on a reinterpretation of ancient Pali chronicles. 
Dharmapala intensified Sinhalese ethno-nationalism in Sri Lanka, which contributed much towards the centralization of state power that questioned the rights of minorities, especially their rights towards political autonomy. These Sinhalese nationalists were advocating for a unitary form of government and mostly opposed power-sharing and federalist discourses.

\subsection{Federalist versus Unitarist Discourse and Minorities' Concerns}

A review of the power-sharing and federalist discourses in Sri Lanka reveals that in the middle of the 1920s, S.W.R.D. Bandaranaike put forward, for the first time, the idea of a federal constitution for the island with three units, one of which was for the Tamils. The Kandyan Sinhalese chiefs also were demanding the same from the Donoughmore Commissioners in the 1930s. No one, including Tamil-speaking politicians, showed any interest in this idea for almost a quarter century after Bandaranaike. It was only in 1949 that a splinter group of the Tamil Congress (TC) formed the Federal Party (FP) led by S.J.V. Chelvanayagam, and demanded territorial and regional based autonomy for the Tamil-speaking peoples living in the north-eastern region (Sivarajah, 2007). Chelvanayagam was criticizing the Citizenship Bill introduced by the United National Party (UNP) government in 1948 that disfranchised a large number of Indian Tamils who had been transported to Sri Lanka in the $19^{\text {th }}$ century as a work force for the British plantation industry. Therefore, he and the splinter group voted against the bill and resigned from the party to form the Federal Party (FP) in 1949. The initial demands of the FP comprised of an amicable solution for the citizenship problem of the Indian Tamils, the immediate cessation of colonizing Sinhalese under agrarian development projects in the traditionally Tamil-speakers-dominated north-eastern region, and the establishment of a federal form of state in order to accommodate the political autonomy claims of Tamil-speaking minorities (Sivarajah, 2007).

It is a noteworthy fact that immediately after independence, the Sinhalese began to advocate for the official status of the Sinhala language under a unitary constitution. The Tamils, however, felt that parity of status would ensure equality of the speakers of the two main languages of the country as well as equal opportunity for individuals. On the other hand, the Sinhalese argued that parity of status for the Tamil language would lead to the disappearance of the Sinhalese language, as it did not have enough resources to compete with Tamil. This irrational argument swept through the Sinhalese electorates. The Tamils emphasized the federalist demand with language recognition when the Federal Party gained popular political support among Tamil-speaking communities in the north-eastern region in the successive general elections. However, ultimately, the Sinhalese political elites' arguments attracted the Sinhalese masses, leading to success in the electoral politics.

In Sri Lanka's state-building process, the question of unitary constitution versus federal constitution was really a question of monopoly of power for the Buddhists versus the Buddhists sharing power with the other ethno-religious groups. The Sinhalese leaders and the Buddhist clergy vehemently opposed the federal demand, equating it to separation or as a step towards separation. Any gain to the Tamils was portrayed as a loss to the Sinhalese. Wilson rightly points out how ideologies regarding land, race, and faith have become interwoven in Sinhalese Buddhist nationalism. In such ideologies, the entire Sri Lanka belongs to the Sinhalese Buddhists; the most important thing is land, the intermediate important thing is the Sinhalese people, and the least important thing is Buddhism. The Tamils' demand for federalism and the creation of a state in their inherited territories was perceived as an evil to which the Sinhalese should never agree (Wilson, 1988). Therefore, the Sinhalese have never made an attempt to understand federalism or to explain the concept of federalism to their electorates, as a positive model of state-building in a plural and competing society.

During the last 60 years, minorities — both the Tamils and the Muslims - have put forward several demands to ensure their political autonomy for their traditional homeland. These ranged from fifty-fifty parliament representation, territorial autonomy, federalism, and self-determination, to a separate state. It is worth noting that the Sinhalese were always advocating a unitary government while the Tamils and the Muslims were always for federation and power-sharing. At the time of the Soulbury Commission in the middle of the 1940s, the Tamils put forward the fifty-fifty claim-50 percent parliamentary representation for the Sinhalese (though the Sinhalese population was proportionately more than 70 percent) and the remaining 50 percent for all other minority groups. Since this claim ultimately failed, they then advocated for establishing a federal form of state. With the formation of extreme forces (in the name of liberation fighters) within the Tamil politics, the Tamils went on to advocate for separation and a separate state. However, all these forms of demands for political autonomy were taken by the Sinhalese-dominated governments in a negative way; their responses to accommodate these demands were also negative and violent in nature.

As Leelarathne (2012) pointed out, one of the main characteristics of the discourse on power-sharing or federalism in Sri Lanka is that these concepts, from the time of their introduction to the country's political 
vocabulary, have been somewhat over-politicized and perceived in different and contesting ways by different political groups. Briefly, federalism became a central political demand of the Tamil ethno-nationalist project, whilst the dominant Sinhalese-Buddhist ethno-nationalist project advocated a unitary state model; hence the debate between federalism or a unitary state became in its outset a part of a political-ideological battle between the two contesting ethno-nationalist projects that presented two approaches for postcolonial nation-building and a continued state formation process [Note 1]. Uyangoda has also rightly highlighted the position of the Sinhalese and the Sinhalese-dominated governments on the minorities' demands for power-sharing and federalism. According to him, the capacity of various Sri Lankan governments to address minority demands for political power-sharing has severely been restricted by the possible as well as the perceived consequences of such arrangements on how state power is currently organized in the country within a unitarist framework adapted from the present constitution. In the politics of electoral competition, as well as of radical nationalist mobilizations in Sinhalese society, there has been a repeated resistance to power-sharing proposals on the ground that deviation from the unitary state framework would facilitate minority secession (See: Uyangoda, 2007). Thus, trapped in ethnicized politics and radical resistance to political reforms, any afford for political reform on the basis of power-sharing in Sri Lanka proved exceedingly difficult from the 1950s onward. For Sinhalese dominant governments, with the emergence of violent ethnic conflict, war has been the key way of maintaining an existing unitary state - with or without reform — while defeating the Tamils' state-making demands within the unitary system.

Similarly, as Uyangoda (2007) argued, the Liberation Tigers of Tamil Eelam (LTTE), which was supposed to represent the grievances of the Tamil community, was also preoccupied with the priorities of state-building concerning what they called the 'Tamils' homeland.' There were genuine affords taken by moderate political leaders for power-sharing and federalism with the ultimate objective of recognizing the Tamils' rights of self-determination and political autonomy within a united Sri Lanka, but in the frame of federalism. However, the formation of terrorist groups, especially the LTTE and its violent acts, clearly propagated to achieve the Tamils' rights of self-determination and political autonomy through secession and a separate [independent] state.

\subsection{Political Agreements and Minorities' Demands for Political Autonomy}

In Sri Lanka's political history, there were many opportunities to accommodate minorities' concerns regarding power-sharing and political autonomy in the north-eastern region through a number of peace agreements. However, most of the initiatives failed due to lack of commitment and mutual suspicion of the objectives of the agreements and the peace process. With the passing of the Sinhala Only Act in 1956, the FP started non-violent agitations against the Act and tried to be pragmatic and make compromises with the Sinhalese dominated government. In 1957, it came to an agreement with Bandaranaike, popularly known as the "Bandaranaike-Chelvanayagam Pact" (B-C Pact). A form of regional autonomy for the north-eastern region with recognition of Tamil as the administrative language was found to be agreeable for both leaders. Though it was far short of federalism, the FP was willing to compromise in the interests of peace and asked the Tamil-speaking people to accept the proposition as an interim measure. This regional autonomy could have been established under a unitary constitution [Note 2]. However, the UNP - the main opposition party at that time-portrayed the compromised solution as a betrayal of the Sinhalese to the Tamils and as giving away of one-third of the country's territory to the Tamils. Several Buddhist monks then marched to Bandaranaike's residence and demanded that Bandaranaike should abrogate the Pact. Bandaranaike obliged them and an opportunity for peace was lost when he publically tore up the B-C Pact on March 1958, without consulting the other party.

It is worth noting the role of opposition politics not only in defeating political agreements but also in downgrading the demands of ethnic minorities. When Bandaranaike and Chelvanayagam tried to reach an agreement in 1957 to grant moderate legislative and limited fiscal autonomy for Tamil-speaking people living in the north-eastern region, the UNP together with Sinhala nationalists and Buddhist monks fiercely campaigned against the agreement to the point of its abortion. The same story was repeated once again in 1965 . When the UNP-led government attempted to negotiate a compromise with Federal Party leaders through another agreement called the "Dadly-Chelva Agreement" in 1965, the then opposition party, the Sri Lanka Freedom Party (SLFP), mobilized campaigns to abort it with other social forces. In fact, as Ghosh rightly argued, if these provisions had been implemented, the B-C Pact would have ushered in a federal system in Sri Lanka in 1957 itself. The implementation of the agreement would have meant a total overhauling of the Regional Council Bill, a draft of which had been prepared in May 1957, and also significant modifications to the Official Language Act of 1956. None of this happened due to the strong agitations made by the major opposition parties (Ghosh, 2003).

As noted above, there were a series of non-supportive arguments and refusals among majority Sinhalese for sharing powers among regionally concentrated ethnic groups as a viable solution for ethnic conflict in Sri Lanka. 
However, with the beginning of thirty years of protracted civil war in the early 1980s, power-sharing, especially the devolution of political power acquired a new discursive identity as a strategic device of peace-building between Tamil militant groups and the Sinhalese-dominated government. However, both groups approached discussions on power-sharing and state reform during the times of peace talks with their own strategic accounts of the battlefield (Leelarathne, 2012). Unfortunately, the end of the civil war with the defeat of the LTTE terrorist group in 2009 created anti-power-sharing sentiments among the majority Sinhalese once again.

Since 1981, with the escalation of the civil war between government forces and the LTTE, Sri Lanka has become a case study and a laboratory for peace-building-cum-state-building endeavors. The proposal to establish District Development Councils (DDCs) is an early example of an endogenous plan, experimented on from 1971-1981. It was neither successful in establishing a strong democratic state nor in facilitating a political framework for state power-sharing among the competing ethnic communities (Jeyasundara-Smith, 2013) [Note 3]. However, it is important to note here that the one and only successful attempt to share power with ethnic minorities under the India-Sri Lanka Agreement signed by the heads of both governments on $29^{\text {th }}$ of July 1987-that was instrumental for the formation of Provincial Councils as power-sharing units at the provincial level - has also failed to devolve essential political powers to the ethnic minorities. The successive central governments controlled by the Sinhalese political elites have been reluctant to fully allow the elected provincial councilors to exercise their constitutionally authorized powers, especially in the affairs of provincial lands and the provincial police force. Furthermore, the central government has arranged a number of controlling and interfering mechanisms over the provincial administration. After the end of civil war, when the government attempted to democratize the provincial council systems in the eastern and northern provinces, minorities expected that they would enjoy at least a considerable level of regional autonomy. But the central government has continued to bring the provincial administration under its ultimate control through a number of means [Note 4].

The most ambitious plan for finding a political solution through devolving powers to date was put forward by the government led by President Chandrika Bandaranaike Kumaratunga from 1995 to 2000, which centered on the formation of Regional Councils and a new role for the regional governors appointed by the President on the advice of the elected Regional Council Chief Minister. Under this proposal, Regional Councils were expected to be given designated powers that would be listed and defined through a new constitution. Although this proposal attracted the support of moderate political parties and leaders, especially of the minorities, it was effectively scuttled by an intransigent attitude adopted by the UNP, the main opposition party at that time under the leadership of Ranil Wickramasinge, who found the proposed state structure a threat to the national unity of the country [Note 5]. A similar history was repeated when Prime Minister Ramil Wickramasinge initiated peace negotiations in 2002 under the facilitation of Norwegian peace brokers. As part of the peace process, by July 2003, proposals were on the negotiation table to form a new Provincial Administrative Council and an Interim Self-Governing Authority for the merged north-eastern province. Although President Kumaratunga had played an active role in changing the position of the LTTE toward the negotiated settlement, the party she led - the SLFP - began to criticize the power-devolving proposal under pressure from Sinhalese nationalists in the south, and Kumaratunga proceeded to block Wickamasinge's power-sharing deal with the minorities (See: Sørbø etal, 2011; ICG, 2007; Paramanathan, 2007).

Sri Lanka's history of peace negotiation failures continued to repeat itself in the government led by President Mahinda Rajapaksa (2005-2015), who argued that political reform was not possible as long as the Tamil Tigers continued to threaten national unity and therefore declined to share powers with minority groups. In January 2006, the government headed by President Rajapaksa convened an All-Party Conference (APC) to fashion creative options that would satisfy minimum expectations as well as provide a comprehensive approach to the resolution of the national question. Rajapaksa made more promising remarks at the APRC's first session, urging it to begin formulating the framework of a political solution to the ethnic conflict by way of the greater devolution of power in an undivided country. The APC produced two reports, namely the "majority report" and the "minority report." The majority report was signed by seven Sinhala, Tamil and Muslim members and proposed a federal solution to resolve the ethnic conflict, but the minority report was signed by four Sinhalese known for their nationalist views and proposed the province as the unit of devolution. Its vision of devolution was much more limited, however, reserving considerably more powers to the center, explicitly rejecting devolution on a language or ethnic basis, recommending a demerger of the north-eastern province and proposing territories to be controlled by the center for security reasons. The only major issue that remained for the APC to discuss was the structure of the state and the allocation of powers to each of the three levels of government. Due to this issue and the government's concern about the military victory of the LTTE separatist war, no meaningful afford was made to implement the APC's recommendations. Once again, the attempt to share powers with 
minorities failed [Note 6].

\subsection{Post-Civil War Context, Minorities and Power-Sharing Discourse}

Sri Lanka's civil war lasted for about thirty years. The LTTE, the major and the powerful armed group represented the grievances of Sri Lankan Tamils had been fighting with the successive Sri Lankan Governments and forces to achieve a separate state for Tamils in the north-eastern region of the country. During the last stage of Norway-facilitated negotiation, in 2003, both opposing parties agreed to explore federal kind of power-sharing mechanism as a political solution to ethnic conflict and to empower the minorities politically. However, later, both parties adopted military means to achieve their intended targets. Minorities' hope for power-sharing became collapsed when the LTTE was defeated by the Sri Lankan military forces in May 2009. With the civil war end, international community continue to pressure on the Sri Lankan government to find a political mechanism to reconcile minorities grievances through sharing political power. However, Sri Lankan government headed by Mahinda Rajapaksa continued to centralize and militarize the governance process which further undermined the minorities' hope for political autonomy. As Jehan Perera (2014) reveals, during the war, the militarization and concentration of power could have been justified on account of the need for speedy decision-making and to marshal all resources for the war effort. But belying the general expectation that the end of the civil war would reduce the role of the armed forces, there was a continuing increase of the military budget and the role of the military in civil administration. This was accompanied by a concurrent undermining of the decentralized institutional autonomy that might have protected pluralism and diversity in Sri Lankan society. The $18^{\text {th }}$ amendment to the constitution, adopted in September 2010, concentrated the powers of appointment of all key state bodies in the hands of the President. The Government's strategy vis-à-vis governance was to ensure that it controlled as much as it could, without leaving independent decision-making powers to other layers of government administration [Note 7].

Regime change in Sri Lanka in the early part of 2015 created hopes not only for minority ethnic groups, but also for the entire world that Sri Lanka will find a lasting solution to its ethnic conflict that considers the concerns of all parties affected, including the adaptation of a minority-friendly political power-sharing model with restructuring of democratic governance. However, about one year has passed from the regime change, no meaningful proposal for power-sharing has yet been proposed or explored by the new government. Furthermore, voices opposing power-sharing with minorities are still prevailing in societal and political domains in different tunes.

An IGC report has clearly argued the nature of Sri Lanka's state and nation-building project. According to this report, Sri Lanka's Sinhalese majority has been steeped in nationalist rhetoric for generations. This has cemented a belief that the island is a Sinhalese Buddhist country with ethnic minorities who regularly exaggerate claims of discrimination. It also has bred deep paranoia about these minorities teaming up with outsiders. For many Sinhalese, Sri Lanka is seen as an outpost of Buddhism in need of protection against outside threats (ICG, 2011). Therefore, ethnic majoritarianism has become so well entrenched among major political parties right from independence, resulting in no scope for minorities to obtain justice through parliamentary methods. More than half a century of so-called democracy in Sri Lanka has not given the Tamil-speaking minorities any hope for power-sharing or political empowerment. Rather, the governments continue to fail to acknowledge legitimate minority grievances that led to conflict, and have made little attempt at promoting and protecting minority rights and freedoms, especially of their right for political autonomy. Despite demands by Tamil and Muslim political parties, successive governments have essentially rejected the need for any political solution based on power-sharing and autonomy arrangements with the Tamil-speaking-minorities predominantly living in the north-eastern part of the country. This attitude still remains among the majority Sinhalese and the major political parties representing them. In the post-war context, the government authorities have openly claimed that any political solution for minorities should be within the limits of the thirteenth amendment of the constitution made in 1987. According to them, the existing constitution is more than enough to solve the problem and there is no necessity to go beyond that (See: India Today, 2011).

The normative conception of recognition of diversity of ethnic identities and accommodating distinct regional identities within a democratic political union is the central theme in federalism. Advocacy for power-sharing, decentralization, regional self-rule, multi-tiered governance and other instrumental aspects of federalism emerge from the above normative principle of unity with diversity (Leelarathne, 2012). Federal and autonomy arrangements are particularly appropriate to accommodate diverse populations, and are likely to counter-balance the demands for territorial, cultural, and religious cleavages. However, in Sri Lanka, political autonomy, power-sharing, and decentralization still remain largely debated projects. While the matter of power devolution is only one aspect of governance, the ability and willingness to devolve such power can pave the way for better 
governance in general. As Perera (2014) indicates, the effective and efficient sharing of power between different groups of elected authorities requires non-partisan institutions to maintain the balance between them.

\section{Conclusion}

The path towards national independence that began with the Donoughmore Commission of 1927 means that Sri Lanka has adopted the trappings of democracy to build a state with a plural society, but in reality, very little has been achieved. The new path that independent rulers have adopted towards building the state has accommodated mainly the interests of the majority population - the Sinhalese - and has continuously undermined the rights of minoritie to share power and become politically autonomous in their traditionally inhabited territories. Minorities, especially Tamils, have long been advocating a federal form of state to enable substantive devolution to their regions, as well as to establish regional representation at the center. However, from the time of their introduction to the political vocabulary, the terms "power-sharing" and "federalism" have been negatively used and interpreted in Sri Lanka. With the defeat of LTTE terrorism, now, minorities are no more demanding separation or even a true form of federation as a political solution to the ethnic conflict. They are ready to be politically autonomous within devolution of the power system in any nature of state structure and any form of government, but they need more devolved powers than the present system.

There have been many political efforts to share political powers among ethnic groups, especially for minorities as part of the state-building process, but most of them have failed due to a number of factors. Firstly, there were huge criticisms and debates over the nature of state and government, as well as the extent of power-sharing to regionally-concentrated ethnic minorities. Secondly, insufficient emphasis was given to power-sharing as a mechanism to promote democracy and the rights of minorities in a plural society. Thirdly, ethno-nationalism of majorities has also played a vital role in undermining the political autonomy of minorities to a greater extent. The politics of opposition has further contributed to sabotage possible forms of power-sharing to minorities agreed on in a number of peace treaties. The ultimate result of these obstacles is the continuous struggle of minorities to situate their political autonomy demands and concerns within the state-building and power-sharing discourse in Sri Lanka.

As a people, minorities in Sri Lanka expect to be treated as equals of the majority Sinhalese. They feel that independence implies equality before the law and equal opportunity in the country. However, the ethnicization of the state and the nation-building project, the lack of cultural unity, and the repeated centralization of state powers in many ways have led to the majority's dominance in socio-cultural, economic, and political affairs of the country while undermining the political, economic, and socio-cultural rights of minorities. Despite there being obvious potentials for decentralization and federalism in Sri Lanka, the attitude of the majority Sinhalese, especially with regards to fearing the attenuation of their power and influence in the center, as well as their anxiety about the eventual fragmentation of the country, has resulted in them failing to act on decentralizing powers to minorities through autonomy and federal arrangement.

With the regime change in the beginning of 2015 , new initiatives are taken by the government to restore democracy in the country including to resolve the long lasting ethnic conflict that centered on the project of sharing powers between ethnic majority and ethnic minorities. Consultations and discussions are going on changing the present constitution. Many proposals placed on sharing powers to ethnic minorities through autonomy and federalism arrangement. However, still both "autonomy" and "federalism" are the contested concepts among the majority Sinhalese in Sri Lanka. If a new constitution retained the unitary definition, whatever power-sharing mechanisms it might contain would be vulnerable to accommodating the due rights of minorities to be politically autonomous. It is the attitude change of the public, politicians and other forces can bring any positive change towards accommodating concern of minorities within state-building and power-sharing discourse and project in the future.

\section{References}

Amarasinghe, Y. R. (2010). Introduction. In Y. R. Amarasinghe (Ed.), Twenty-two years of devolution: An evaluation of the working of provincial councils in Sri Lanka (pp. 1-14). Rajagiriya (Colombo): Institute for Constitutional Studies.

Bandara, A. M. (2010). Provincial public administration. In L. Marasinghe \& J. Wickramaratne (Eds.), $13^{\text {th }}$ amendment: Essays on practice (pp. 164-189). Pannipitiya, Sri Lanka: Stamford Lake Publication.

De Silva, K. M. (2001). Power sharing arrangements in Sri Lanka. The Hague, Netherlands: Netherlands Institute of International Relations.

Dissanayke, T. D. S. A. (2005). War or peace in Sri Lanka. Mumbai: Popular Prakashan Pvt Ltd. 
Eichhorst, K. (2010). Asymmetric autonomy and power sharing for Sri Lanka: a political solution to ethnic conflict. In M. Weller, \& K. Nobbs (Eds.), Asymmetric autonomy and the settlement of ethnic conflicts (pp. 252-277). Philadelphia: University of Pennsylvania. http://dx.doi.org/10.9783/9780812205756.252

Ghosh, P. S. (2003). Ethnicity versus nationalism. Colombo: Vijitha Publications.

Government Publication Bureau (GPB). (2010). Eighteenth amendment to the constitution. Colombo: GPB.

Government Publication Bureau (GPB). (2015). Nineteenth amendment to the constitution. Colombo: GPB.

Ground View. (2010). The $18^{\text {th }}$ amendment to the constitution: process and substance. Colombo. Ground View. Retrieved June 16, 2014 from http://groundviews.org/2010/09/02/the-18th-amendment-to-the-constitution-process-and-substance/

Hellmann-Rajanayagam, D. (2009). Drawing in treacle: Mediation efforts in Sri Lanka, 1983 to 2007. International Quarterly for Asian Studies, 40(1-2), 59-96.

India Today. (2011, August 8). SL war crimes: Gotabaya hits out at Jayalalithaa; confident of Indian support. Retrieved

from http://indiatoday.intoday.in/story/sl-war-crimes-gotabaya-hits-out-at-jayalalithaaconfident-of-indian-support $/ 1 / 147475 . \mathrm{html}$

International Crisis Group (ICG). (2011). Reconciliation in Sri Lanka: Harder than ever. London: IGC.

International Crisis Group (IGC). (2007). Sinhala nationalism and the elusive southern consciousness. London: IGC.

Jeyasundara-Smith, S. (2013). In pursuit of hegemony: Politics and state building in Sri Lanka (Unpublished doctoral dissertation). Erasmus University Rotterdam, Rotterdam, Netherlands.

Leelarathne, S. (2012). Politicizing federalism: Sri Lankan case. Switzerland: Institute of Federalism.

Manikkalingam, R. (2003). A unitary state, a federal state or two separate states. Colombo: Social Scientist Association.

Matthews, B. (1982). District development councils in Sri Lanka. Asian Survey, 22(11), 1117-1134. http://dx.doi.org/10.2307/2643983

Paramanathan, M. (2007). Peace negotiations of Sri Lankan Conflict in 2000-2006: The ceasefire agreement facilitated by Norway is at stake (Unpublished master's thesis). Jönköping International Business School, Jönköping University, Jönköping, Sweden.

Peebles, P. (2006). The history of Sri Lanka. Westport, CT: Greenwood.

Perera, J. (2012). Political challenges in post-war Sri Lanka. ISAS Insights, 194, 1-7.

Perera, J. (2014). Decentralization: Moots reverse centralization of power as a road map for better governance. LMD: The voice of business. Retrieved from http://lmd.lk/2014/02/01/devolution-debate/

Perera, S. (2001). The ethnic conflict in Sri Lanka: A historical and sociopolitical outline. Washington DC: World Bank.

Ponnambalam, S. (1983). Sri Lanka: national conflict and the Tamil liberation struggle. London: Zed Book Ltd.

Sarjoon, A. (2011). Changing dynamics of minority rights discourse in Sri Lanka: A study of Muslims demand for autonomy in the eastern Sri Lanka (Unpublished M.Phil thesis). University of Colombo, Colombo, Sri Lanka.

Sivakumar, N. (2013). Development via sub-national government in Sri Lanka: Challenges and opportunities. International Journal of Education and Research, 1(11), 1-14.

Sivarajah, A. (2007). The Federal Party of Sri Lanka. Colombo-Chennai: Kumaran Book House.

Sørbø, G., Goodhand, J., Klem, B., Nissen, A. E., \& Selbervik, H. (2011). Pawns of peace: Evaluation of Norwegian peace efforts in Sri Lanka, 1997-2009. Oslo: Norad.

Uditha, E., \& Mahen, G. (2009). Devolution of powers: The Sri Lankan experience. Colombo: Kamalasabayson Foundation.

Uyangoda, J. (2007). Ethnic conflict in Sri Lanka: Changing dynamics. Washington: The East-West Center.

Wickramaratne, J. (2010). The 1972 constitution in retrospect. In T. Jeyatilleke (Ed.), Srimavo (pp. 1-12). Colombo: Bandaranaike Museum Committee. 
Wilson, J. (1988). The break-up of Sri Lanka. London: C.Hurst.

Wriggins, H. W. (1982). Sri Lanka in 1981: Year of austerity, development councils and communal disorders. Asian Survey, 22(2), 171-179. http://dx.doi.org/10.2307/2643944

\section{Notes}

Note 1. For extensive analysis of different perspectives of supports for and opposition to unitarism and federalism in Sri Lanka, see: De Silva 2001; Manikkalingam 2003 \& Leelarathne 2012.

Note 2. The Bandaranaike-Chelvanayagam Pact (known as B-C Pact) was signed on 26 July 1957. It was the culmination of negotiation that took place between the government and the Tamil leaders since the Federal Party conference held in August 1956. The important points of agreement that were reached after considerable bargaining between the two sides were: (i) Regional areas to be defined in the Bill itself by embodying them in a schedule thereto (ii) The Northern Province was to form one regional area whilst the Eastern Province is to be divided into two or more regional areas (iii) A provision is to be made in the Bill to enable two or more regions to amalgamate even beyond provincial limits; and for one to divide itself subject to ratification by parliament. Further provision is to be made in the Bill for two or more regions to collaborate for specific purposes or common interests. For further details on B-C Pact, see: Chosh 2003; Dissanayake 2005; ICG 2007.

Note 3. For more details on DDC system, see, Matthews 1982; Wriggins 1982 \& Hellmann-Rajanayagam 2009.

Note 4. For extensive analysis on the functioning and the issues related with the administration of provincial council, see: Uditha \& Mahen 2009; Amarasinge 2010; Bandara 2010 \& Sivakumar 2013.

Note 5. For more details on the historical development and the nature of the devolution arrangement and the draft constitution of the People's Alliance (PA) government, See: Chosh 2003; Dissanayake 2005; ICG 2007; Sarjoon 2011.

Note 6. For more details on the APC initiatives and its recommendations, see: ICG 2007; Eichhorst 2010:252-277.

Note 7. The $18^{\text {th }}$ Amendment to the constitution made in 2010 restored the President the full and untrammeled powers of appointment to the highest positions of the state independent commissions that the $17^{\text {th }}$ Amendment had taken away from the Presidency a decade earlier. It also strengthened the presidency by doing away with the two-term limit on office and giving the incumbent President, and those who succeed him, the right to contest the presidential election any number of times. However, the Presidential power to appoint the key posts in the important government bodies has now been transformed to Constitutional Council established through the $19^{\text {th }}$ amendment to the constitution adopted in April 2015 which is identified as the major reform that controls the President's power over state institutions. For more discussion on $18^{\text {th }}$ amendment and details on the specific arrangements of $19^{\text {th }}$ amendments, see: Government Publication Bureau 2010; Ground View 2010. Government Publication Bureau 2015.

\section{Copyrights}

Copyright for this article is retained by the author(s), with first publication rights granted to the journal.

This is an open-access article distributed under the terms and conditions of the Creative Commons Attribution license (http://creativecommons.org/licenses/by/3.0/). 